\title{
Excitability and contractility of skeletal muscle engineered from primary cultures and cell lines
}

\author{
ROBERT G. DENNIS, PAUL E. KOSNIK II, MARK E. GILBERT, AND JOHN A. FAULKNER \\ ${ }^{1}$ Muscle Mechanics Laboratory, Institute of Gerontology, University of Michigan, \\ Ann Arbor 48109-2007; and ${ }^{2}$ Gilbert Engineering, Inc., Ann Arbor, Michigan 48103-9005
}

Received 19 May 2000; accepted in final form 1 September 2000

\begin{abstract}
Dennis, Robert G., Paul E. Kosnik II, Mark E. Gilbert, and John A. Faulkner. Excitability and contractility of skeletal muscle engineered from primary cultures and cell lines. Am J Physiol Cell Physiol 280: C288-C295, 2001.-The purpose of this study was to compare the excitability and contractility of three-dimensional skeletal muscle constructs, termed myooids, engineered from $\mathrm{C}_{2} \mathrm{C}_{12}$ myoblast and $10 \mathrm{~T}^{1} 12$ fibroblast cell lines, primary muscle cultures from adult $\mathrm{C} 3 \mathrm{H}$ mice, and neonatal and adult Sprague-Dawley rats. Myooids were $12 \mathrm{~mm}$ long, with diameters of 0.1-1 mm, were excitable by transverse electrical stimulation, and contracted to produce force. After $\sim 30$ days in culture, myooid cross-sectional area, rheobase, chronaxie, resting baseline force, twitch force, time to peak tension, one-half relaxation time, and peak isometric force were measured. Specific force was calculated by dividing peak isometric force by cross-sectional area. The specific force generated by the myooids was $2-8 \%$ of that generated by skeletal muscles of control adult rodents. Myooids engineered from $\mathrm{C}_{2} \mathrm{C}_{12}-10 \mathrm{~T}^{1 / 2}$ cells exhibited greater rheobase, time to peak tension, and one-half relaxation time than myooids engineered from adult rodent cultures, and myooids from $\mathrm{C}_{2} \mathrm{C}_{12}-10 \mathrm{~T} 1 / 2$ and neonatal rat cells had greater resting baseline forces than myooids from adult rodent cultures.
\end{abstract}

tissue engineering; myooid; myogenesis; isometric force; rodent tissue culture

IN VITRO SKELETAL MUSCLE TISSUE engineering involves culturing isolated myoblasts and fibroblasts in an environment conducive to the formation of a three-dimensional tissue construct. Cell sources employed to engineer such constructs include the $\mathrm{C}_{2} \mathrm{C}_{12}$ mouse muscle sarcoma cell line $(15,26,29)$, embryonic avian muscles $(1,21-23,25,28)$, and skeletal muscles of neonatal (21) and adult $(5,17,27)$ mammals. To promote formation of a three-dimensional structure, cells have been cultured in collagen gels $(1,15,21,26,27,30)$, on an elastic membrane $(1,21,28)$, or between two stationary anchor points to which the cell monolayer remains attached $(5,21,23)$. Collagen gels provide a scaffold for the cells and define the size and shape of the construct but may interfere with the force and power production of the myotubes. In the absence of an artificial scaffold, embryonic avian cells were developed into cylindrical

Address for reprint requests and other correspondence: R. G. Dennis, 300 N. Ingalls, Rm. 956, Ann Arbor, MI 48109-2007 (E-mail: bobden@umich.edu and bdennis@ai.mit.edu). organoids when subjected to uniaxial mechanical strain (28) or when cultured on prestrained elastic substrates (21). In one report, the isometric force of organoids was measured by lateral displacement of the organoids with a calibrated microneedle after elevation of the extracellular $\mathrm{K}^{+}$concentration (28).

Cylindrical musclelike structures, termed myooids, were engineered from cocultures of primary mammalian myoblasts and fibroblasts (5), without a preexisting scaffold, the application of uniaxial mechanical strain, or prestressed substrates. Myooids were supported under tension between artificial tendons of laminin-coated silk suture; organoids were attached to stainless steel screens. In the case of myooids, the laminin-coated silk suture segments served as flexurally compliant artificial tendons, permitting easy attachment to a force transducer for functional evaluation. The excitability and contractility of myooids were measured with a force transducer by transverse electrical stimulation between parallel electrodes and measurement of axial force development (5). When normalized for cross-sectional area (CSA), the specific force $\left(\mathrm{sP}_{\mathrm{o}}\right)$ generated by myooids was not different from that of organoids, both being equivalent to $\sim 1 \%$ of the $\mathrm{sP}_{\mathrm{o}}$ of adult rodent skeletal muscle (5).

The purpose of this study was to compare the CSA, excitability, and contractility of myooids engineered from cocultures of $\mathrm{C}_{2} \mathrm{C}_{12}$ myoblast and $10 \mathrm{~T}^{1} 1 / 2$ fibroblast cell lines and primary cultures from the skeletal muscles of adult mice and neonatal and adult rats. For simplicity in terminology, myooids engineered from $\mathrm{C}_{2} \mathrm{C}_{12}-10 \mathrm{~T}^{1 / 2} / 2$ cells, adult mouse, neonatal rat, and adult rat are referred to as $\mathrm{C}_{2} \mathrm{C}_{12}-10 \mathrm{~T} 1 / 2$ myooids, adult mouse myooids, neonatal rat myooids, and adult rat myooids, respectively. On the basis of preliminary data and observations, our working hypothesis is that the excitability and contractility of myooids engineered from primary cell sources do not differ, while the excitability and contractility of $\mathrm{C}_{2} \mathrm{C}_{12}-10 \mathrm{~T}^{1 / 2}$ myooids are lower than those of myooids engineered from primary cells. Our specific hypotheses are that 1) the measures of excitability and contractility do not differ among myooids engineered from primary cell sources and 2)

\footnotetext{
The costs of publication of this article were defrayed in part by the payment of page charges. The article must therefore be hereby marked "advertisement" in accordance with 18 U.S.C. Section 1734 solely to indicate this fact.
} 
$\mathrm{C}_{2} \mathrm{C}_{12}-10 \mathrm{~T}^{1} 1 / 2$ myooids have greater rheobase, chronaxie, time to peak tension, and one-half relaxation time and lower twitch force and peak isometric force than primary rodent myooids.

\section{MATERIALS AND METHODS}

The methods for engineering myooids from primary cultures of rat soleus (SOL) muscles and the methods and instrumentation for measuring the excitability and contractility of myooids have been described in detail (5). For the formation of neonatal rat myooids, modifications were made in the surgical techniques for the removal of muscle tissue and in the composition of the cell culture and tissue dissociation media. The formation of myooids from established cell lines was accomplished only with the coculture of $\mathrm{C}_{2} \mathrm{C}_{12}$ myoblasts with $10 \mathrm{~T}^{1 / 2}$ fibroblasts and the use of a reducedserum culture medium $(\mathrm{CM})$.

Media and solutions. The CM were growth medium (GM) and differentiation medium (DM), which have been described previously (5). For the culture of $\mathrm{C}_{2} \mathrm{C}_{12}$ cells, a CM was prepared [465 ml of DMEM (catalog no. 11995-065, GIBCO $\mathrm{BRL}$ ), $35 \mathrm{ml}$ of fetal bovine serum (FBS; catalog no. 10437036, GIBCO BRL), and $100 \mathrm{U} / \mathrm{ml}$ penicillin G]. For storing neonatal muscle during harvesting, mincing solution (4) was prepared, brought to $\mathrm{pH} 7.4$, and sterilized through $0.22-\mu \mathrm{m}$ filters. Preincubation medium (PIM) was prepared as described previously (5). The CM and PIM were stored at $4^{\circ} \mathrm{C}$ until use. Tissues from adult animals were dissociated in an "adult" dispase-and-collagenase (D \& C) solution $[4 \mathrm{U} / \mathrm{ml}$ dispase (catalog no. 17105-041, GIBCO BRL) and $100 \mathrm{U} / \mathrm{ml}$ type IV collagenase (CLS 4, Worthington) in DMEM]. The neonatal muscle tissue was dissociated using "neonatal" D \& $\mathrm{C}$ (ND \& C) solution [4 U/ml dispase (catalog no. 17105-041, GIBCO BRL) and $100 \mathrm{U} / \mathrm{ml}$ type IV collagenase (CLS 4, Worthington) in mincing solution]. D \& C and ND \& C solutions were prepared immediately before use and sterilized through $0.22-\mu \mathrm{m}$ filters.

Isolation and culture of primary cells. All animals were handled in accordance with the Guide for the Care and Use of Laboratory Animals. Neonatal Sprague-Dawley rats were delivered in litters of 11-14 within 1 day of birth from Charles River (Wilmington, MA), and muscle tissue was harvested from all the pups in the litter. On arrival, neonates were placed in 15-cm glass petri dishes on ice for $0.75-1.5 \mathrm{~h}$ as a general anesthesia. In a biological safety cabinet, the anesthetized pups were completely immersed in $70 \%$ ethanol before surgical removal of the muscle tissue. The muscles from the fore- and hindlimbs were removed and placed in 8 $\mathrm{ml}$ of mincing solution. ND \& C solution $(12 \mathrm{ml})$ was added, and the tissue was dissociated by magnetic stirring at room temperature for $1.5 \mathrm{~h}$. The magnetic stir bar was removed, and the slurry was centrifuged for $15 \mathrm{~min}$ at $1,000 \mathrm{~g}$. The pellet was resuspended in $20 \mathrm{ml}$ of $0.1 \%$ (wt/vol) collagenase type IV (Worthington) in Ham's F-12 nutrient medium (GIBCO BRL) and placed in a shaker bath at $37^{\circ} \mathrm{C}$ for $1.5 \mathrm{~h}$. The pellet was then centrifuged for $15 \mathrm{~min}$ at $1,000 \mathrm{~g}$ and resuspended in GM. Cells were counted with a hemocytometer, and the solution was adjusted to achieve the desired cell plating density $\left(1 \times 10^{6}, 1 \times 10^{5}, 1 \times 10^{4}, 1 \times 10^{3}, 1 \times 10^{2}\right.$, or 10 cells $/ \mathrm{cm}^{2}$ ). Two milliliters of the cell suspension were plated onto each 35-mm culture dish with anchors in place, and the culture dishes were placed in a water-saturated incubator with $5 \% \mathrm{CO}_{2}$ at $37^{\circ} \mathrm{C}$.

For the harvesting of satellite cells and fibroblasts from adult (5- to 6-mo-old) Sprague-Dawley rats and $\mathrm{C} 3 \mathrm{H}$ mice, animals were anesthetized with an intraperitoneal injection of pentobarbital sodium and the whole SOL or extensor digitorum longus (EDL) muscles were surgically removed. Each rat SOL muscle was sliced into six strips longitudinally from tendon to tendon; the mouse SOL and EDL muscles were left whole. The muscles and muscle strips were pinned at slack length in 35-mm culture dishes with Sylgard (Dow Corning, Midland, MI), preincubated for $50 \mathrm{~h}$ in PIM in a water-saturated incubator with $5 \% \mathrm{CO}_{2}$ at $37^{\circ} \mathrm{C}$, and then dissociated in $7.5 \mathrm{ml}$ of $\mathrm{D} \& \mathrm{C}$ solution per strip or whole muscle for $3-4 \mathrm{~h}$ at $37^{\circ} \mathrm{C}$. To achieve the greatest possible yield of satellite cells, the dissociated tissue was plated directly into the prepared culture dishes with laminin-coated suture anchors in place, without an attempt to filter the dissociated cells from the tissue debris. The plating density was therefore expressed as the amount of muscle tissue dissociated for each myooid in each $35-\mathrm{mm}$ culture plate. Optimal plating densities for primary cells from rat and mouse muscle had been determined previously, with myooid size and contractility as the parameters to be optimized. The rat SOL muscle was plated at $13 \mathrm{~g}$ of tissue per plate, and the adult mouse SOL and EDL muscles were plated at 10 and $13 \mathrm{~g}$ of dissociated tissue per plate, respectively. For primary cultures, beginning at $48 \mathrm{~h}$ after cell plating, the GM was replaced every $48 \mathrm{~h}$ until the cells became confluent, which typically required 3-8 days. One day after the cells reached confluence, the medium was replaced with DM, and the cells were fed three times per week thereafter. Shortly after they were switched to DM, the myocytes fused to form multinucleated myotubes that began to contract spontaneously.

Culture of cells from established lines. Myoblasts of the $\mathrm{C}_{2} \mathrm{C}_{12}$ cell line (CRL-1772; American Type Culture Collection, Rockville, MD) formed myooids only when cultured with $10 \mathrm{~T}^{1 / 2} 2$ fibroblasts (provided by Dr. G. Salvatori). In preliminary experiments, plating densities of $1 \times 10^{6}, 1 \times 10^{5}, 1 \times$ $10^{4}, 1 \times 10^{3}$, and $1 \times 10^{2}$ cells $/ \mathrm{cm}^{2}$ were used for cocultured cells and for monocultured $\mathrm{C}_{2} \mathrm{C}_{12}$ cells. On the basis of the results from the preliminary experiments, for the cocultures of $\mathrm{C}_{2} \mathrm{C}_{12}$ and $10 \mathrm{~T}^{1} 1 / 2$ cells the plating density was fixed at $1 \times$ $10^{5}$ cells $/ \mathrm{cm}^{2}$. The myoblasts and fibroblasts were combined to produce cocultures with $30-80 \% \mathrm{C}_{2} \mathrm{C}_{12}$ cells in increments of $10 \%$. The $\mathrm{C}_{2} \mathrm{C}_{12}$ and $10 \mathrm{~T}^{1} / 2$ cells were mixed in CM, plated, and allowed to remain in culture for $48 \mathrm{~h}$ before the first media change. Until the myooids were evaluated, regular media changes were carried out every $48-72 \mathrm{~h}$. There were no differences in the excitability or contractility of the myooids formed from different initial ratios of cell types. Consequently, these groups, termed $\mathrm{C}_{2} \mathrm{C}_{12}-10 \mathrm{~T}^{1 / 2}$ myooids, were pooled for subsequent analysis.

Myooid formation. For all cell sources, myooids formed by delamination of the monolayer of cultured cells from the Sylgard substrate. Artificial tendons of silk suture with one end frayed and coated with natural mouse laminin were employed, and the Sylgard substrate in each dish was coated with laminin at a density of $1.0 \mu \mathrm{g} / \mathrm{cm}^{2}$. The failure rate due to contamination of the culture plates was $<5 \%$ for each experiment. Contaminated plates were discarded immediately and not included in subsequent analysis. The $\mathrm{C}_{2} \mathrm{C}_{12}{ }^{-}$ $10 \mathrm{~T}^{1} / 2$ myooids frequently did not detach completely from the Sylgard substrate. To aid detachment, the closed tips of a pair of sterile no. 5 forceps (Fine Science Tools) were used to gently tease the myooid from the substrate. The myooids were then allowed to remodel for $\geq 72 \mathrm{~h}$ before evaluation.

Experimental groups. The five experimental groups, based on the source of the cells for the myooids, were $\mathrm{C}_{2} \mathrm{C}_{12}$ and $10 \mathrm{~T}^{1 / 2}$ cells, adult mouse SOL muscle, adult mouse EDL muscle, neonatal rat limb muscle, and adult rat SOL muscle. The values of 13 experimental variables were determined for 
each of the 5 experimental groups. Nine variables were measured directly: morphology (diameter), excitability [rheobase $\left(R_{50}\right)$ and chronaxie $\left(C_{50}\right)$, isometric force measurements [passive baseline $\left(\mathrm{P}_{\mathrm{b}}\right)$, peak twitch $\left(\mathrm{P}_{\mathrm{t}}\right)$, and peak isometric force $\left(\mathrm{P}_{\mathrm{o}}\right)$ ], and the time-dependent variables [time to peak twitch force (TPT), rate of force development $(\mathrm{dP} / \mathrm{d} t)$, and one-half relaxation time $\left.\left(\mathrm{RT}_{1 / 2}\right)\right]$. Four additional parameters were calculated from the measured variables: CSA of the myooid from the diameter, $\mathrm{sP}_{\mathrm{o}}$ by dividing $\mathrm{P}_{\mathrm{o}}$ by the CSA, and the ratios of peak twitch to peak isometric force $\left(\mathrm{P}_{t} / \mathrm{P}_{\mathrm{o}}\right)$ and passive baseline to peak isometric force $\left(\mathrm{P}_{b} / \mathrm{P}_{\mathrm{o}}\right)$. Since CSA was calculated directly from diameter, the diameter was not included in the statistical analysis, leaving 12 experimental variables.

Histology. After contractile properties were measured, myooids were pinned at the length at which they were cultured $\left(L_{\mathrm{c}}\right)$ and fixed for $4 \mathrm{~h}$ at $4^{\circ} \mathrm{C}$ in Karnovsky's solution $(0.1$ $\mathrm{M}$ sodium cacodylate buffer with $3 \%$ formaldehyde and $3 \%$ glutaraldehyde at $\mathrm{pH}$ 7.4). Myooids were rinsed three times (30 min, $30 \mathrm{~min}$, and $4 \mathrm{~h}$ ) with cacodylate buffer ( $\mathrm{pH} 7.4$ ) with $7.5 \%$ sucrose. Myooids were postfixed in $1 \%$ osmium tetroxide for $2 \mathrm{~h}$ at room temperature, dehydrated in graded concentrations of ethanol and propylene oxide, and embedded in Epon (Eponate 12 resin; Ted Pella, Redding, CA) for light microscopy. Cross sections were cut $600 \mathrm{~nm}$ thick for light microscopy and stained with $1 \%$ toluidine blue.

Data collection and analysis. The methods for measuring the excitability and contractility of myooids have been described in detail previously (5). Culture times were defined from the time of cell plating, rather than from the time of myooid formation. The myooid diameter was defined as the minimum diameter of each myooid along the length between the anchors. Myooid diameter was measured using a calibrated eyepiece reticle while each myooid was viewed through a $\times 10$ objective lens on an inverted microscope (Zeiss Axiovert 25, Thornwood, NY). CSA was calculated from the measured diameter, assuming a circular cross section. All contractile properties were measured $32 \pm 4$ days after the cells were plated and $\geq 72 \mathrm{~h}$ after formation of each myooid. Myooid temperature was maintained at $37 \pm 1^{\circ} \mathrm{C}$ during the measurement of contractile properties by use of a heated aluminum platform.

For measurements of excitability and contractility, one of the artificial tendons of each myooid was affixed to a force transducer. Myooids were excited by electrical stimulation between two parallel platinum wire electrodes. $\mathrm{P}_{\mathrm{b}}$ was measured as the average baseline passive force preceding the onset of stimulation. Data files for each $\mathrm{P}_{t}$ and $\mathrm{P}_{\mathrm{o}}$ trace were recorded and stored for subsequent analysis. Force data were collected at $200 \mathrm{samples} / \mathrm{s}$. A median filter of rank 2 was applied to all raw force data before storage to minimize digitization noise without causing a phase delay for rapidly changing forces. $\mathrm{P}_{\mathrm{t}}$ and $\mathrm{P}_{\mathrm{o}}$ were determined after subtraction of $P_{b}$ from the total force values. Excitability of the myooids was measured by first applying a long-duration (4- to 6-ms) single stimulus pulse while adjusting the stimulus intensity to achieve a twitch of $50 \% \mathrm{P}_{\mathrm{t}}$. The resulting stimulus intensity (voltage) was divided by the electrode separation to determine the field strength $(\mathrm{V} / \mathrm{mm})$ required to elicit a $50 \%$ twitch, which we define as $R_{50}$. The stimulus intensity was then fixed to twice $R_{50}$, and the stimulus duration was adjusted until twitch forces of $50 \%$ of $\mathrm{P}_{t}$ were once again achieved. The resulting stimulus duration was defined as $\mathrm{C}_{50}$. The time-dependent twitch force parameters were measured directly from the stored data traces for each myooid. TPT was measured from the onset of force development until the peak twitch value was attained. $\mathrm{dP} / \mathrm{d} t$ was determined as the average slope of the rising portion of the twitch force trace, measured between 20 and $80 \%$ of $\mathrm{P}_{\mathrm{t}}$. The time from the onset of relaxation to $50 \%$ of $\mathrm{P}_{\mathrm{t}}$ was defined as $\mathrm{RT}_{1 / 2}$.

For statistical analysis, the data were analyzed using the Tukey-Kramer method for all pairwise comparisons between treatment means, with $\alpha$ set a priori to 0.05 . The TukeyKramer method is conservative when sample sizes are unequal, as in this analysis, and is more sensitive than the Bonferroni or the Scheffé method, providing narrower confidence intervals for a given $\alpha$. Each variable was analyzed separately, with calculations of estimators and test statistics performed in Microsoft Excel 97. The $t$-test statistic was calculated using values of the studentized range distribution $q(1-\alpha, r, v)$ (Ref. 14, appendix table). The test, which assumes all independent variables are normally distributed, was applied for each variable when the $F$ ratio indicated significant differences between means.

Myooid life span. Myooids from three of the experimental groups (adult mouse SOL and neonatal and adult rat SOL) were maintained in culture beyond 30 days to determine the time over which they remained viable. Myooids continue to contract spontaneously and may be functionally evaluated until the point at which they mechanically fail, typically by breaking at some point between the suture anchors. We define the time from cell plating until the myooid breaks as the "life span" of the myooid. Life spans were not observed for adult mouse EDL myooids, because a culture contamination at the preincubation stage left only enough tissue for the formation of four myooids, all of which were used for measurement of excitability and contractility. $\mathrm{C}_{2} \mathrm{C}_{12}-10 \mathrm{~T}^{1} / 2$ myooids were not included in the life span study, because excitability and contractility were so variable for this group that a large " $n$ " was required to achieve statistical significance for comparisons. No contractile function tests were performed on any myooids used for the life span study. Myooids were fed and monitored three times each week until they failed by mechanical breakage between the suture anchors.

\section{RESULTS}

Spontaneous activity of myotubes and myooids in culture. When the spontaneous contractile activity of the myotubes before delamination of the monolayer was compared, qualitative and quantitative differences were evident. The $\mathrm{C}_{2} \mathrm{C}_{12}$ myotubes contracted singly and sporadically and at a frequency of $3-5 \mathrm{~Hz}$, whereas the sheet of myotubes from the primary explants contracted regularly and vigorously as a syncytium, with a frequency of $0.5-1.5 \mathrm{~Hz}$. Under low-power magnification, spontaneous contractions were observed in all the myooids from primary cells. In contrast, $\mathrm{C}_{2} \mathrm{C}_{12}-10 \mathrm{~T}[1 / 2]$ myooids often appeared inactive until electrically excited. Occasionally, large-amplitude spontaneous contractions occurred after electrical stimulation of the $\mathrm{C}_{2} \mathrm{C}_{12}-10 \mathrm{~T}^{1} 1 / 2$ myooids.

Myooid formation. Monocultured $\mathrm{C}_{2} \mathrm{C}_{12}$ cells never formed a myooid regardless of the plating density, although in all cases they formed a monolayer of myoblasts and myotubes on the substrate. After $\sim 3-10$ days in culture, the monolayer of monocultured $\mathrm{C}_{2} \mathrm{C}_{12}$ cells delaminated in small (1- to 2-mm-diameter) irregular patches, resulting ultimately in disintegration of the monolayer. In contrast, the cocultures of $\mathrm{C}_{2} \mathrm{C}_{12}$ cells and the 10T $1 / 2$ fibroblasts formed myooids $\sim 50 \%$ of the time, independent of the mixing ratio of the cells, 
Table 1. CSA, excitability, and time-dependant isometric contractility of myooids

\begin{tabular}{|c|c|c|c|c|c|c|c|}
\hline $\begin{array}{l}\text { Experimental } \\
\text { Group }\end{array}$ & $n$ & $\mathrm{CSA}, \mathrm{mm}^{2}$ & $\mathrm{R}_{50}, \mathrm{~V} / \mathrm{mm}$ & $\mathrm{C}_{50}, \mu \mathrm{s}$ & TPT, ms & $\mathrm{dP} / \mathrm{d} t, \mu \mathrm{N} / \mathrm{ms}$ & $\mathrm{RT}_{1 / 2}, \mathrm{~ms}$ \\
\hline $\mathrm{C}_{2} \mathrm{C}_{12}-10 \mathrm{~T}^{1 / 2}$ & 19 & $0.214 \pm 0.050$ & $1.93 \pm 0.07$ & $416 \pm 41$ & $114 \pm 5$ & $2.6 \pm 0.4$ & $1,343 \pm 254$ \\
\hline Neonatal rat & 11 & $0.072 \pm 0.021$ & $1.01 \pm 0.10$ & $603 \pm 89$ & $64 \pm 6$ & $0.8 \pm 0.1$ & $81 \pm 4$ \\
\hline Adult rat SOL & 11 & $0.153 \pm 0.072$ & $1.02 \pm 0.06$ & $526 \pm 30$ & $65 \pm 4$ & $3.2 \pm 0.5$ & $100 \pm 18$ \\
\hline Mouse SOL & 7 & $0.030 \pm 0.011$ & $0.87 \pm 0.12$ & $530 \pm 109$ & $53 \pm 5$ & $7.2 \pm 3.2$ & $43 \pm 4$ \\
\hline Mouse EDL & 4 & $0.024 \pm 0.009$ & $0.54 \pm 0.08$ & $550 \pm 96$ & $50 \pm 4$ & $5.1 \pm 3.8$ & $90 \pm 47$ \\
\hline Mouse pooled & 11 & $0.027 \pm 0.008$ & $0.75 \pm 0.09$ & $537 \pm 74$ & $52 \pm 3$ & $6.3 \pm 2.3$ & $62 \pm 19$ \\
\hline
\end{tabular}

Values are means \pm SE. CSA, cross-sectional area of the myooid calculated directly from the minimum myooid diameter; SOL, soleus muscle from adult animals; EDL, extensor digitorum longus muscle from adult animals; $\mathrm{R}_{50}$, rheobase; $\mathrm{C}_{50}$, chronaxie; TPT, time to peak twitch tension $\left(\mathrm{P}_{\mathrm{t}}\right) ; \mathrm{dP} / \mathrm{d} t$, rate of twitch force development from 20 to $80 \% \mathrm{P}_{\mathrm{t}}$; $\mathrm{RT}_{1 / 2}$, one-half relaxation time from $\mathrm{P}_{\mathrm{t}}$; mouse pooled data, mouse SOL + mouse EDL data.

in the range of $30-80 \% \mathrm{C}_{2} \mathrm{C}_{12}$ cells. The inability of the monocultured $\mathrm{C}_{2} \mathrm{C}_{12}$ cells to form myooids appeared to be attributable to the absence of fibroblasts. The fibroblasts likely function to provide an extracellular matrix that strengthens the monolayer before delamination, as reported earlier by Vandenburgh et al. (28).

Since no differences were observed between groups of myooids engineered from different proportions of $\mathrm{C}_{2} \mathrm{C}_{12}$ cells and fibroblasts, these data were pooled for subsequent analysis. The larger diameters of the $\mathrm{C}_{2} \mathrm{C}_{12}-10 \mathrm{~T}^{1 / 2} 2$ myooids (Table 1 ) suggest incomplete remodeling of the monolayer of cells into a cylindrical myooid within the allotted $72 \mathrm{~h}$. The success rate for myooid formation using neonatal cells was $>95 \%$ at plating densities of $1 \times 10^{6}$ cells $/ \mathrm{cm}^{2}, \sim 50 \%$ at $1 \times 10^{5}$ cells $/ \mathrm{cm}^{2}$, and $0 \%$ for lower plating densities. In contrast, the cells from adult rat cultures formed myooids $\sim 95 \%$ of the time when plated on $1.0 \mu \mathrm{g} / \mathrm{cm}^{2}$ laminin at $13 \mathrm{mg}$ of dissociated tissue per plate.

Excitability and contractility. The mean values for each of the 12 experimental variables in each of the 5 experimental groups are summarized in Tables 1 and 2 . Table 1 shows mean values for CSA, excitability $\left(R_{50}\right.$ and $\mathrm{C}_{50}$ ), and the time-dependent isometric twitch parameters (TPT, $\mathrm{dP} / \mathrm{d} t$, and $\mathrm{RT}_{1 / 2}$ ) of myooids. The mean values for the isometric contractility measures $\left(\mathrm{P}_{\mathrm{b}}, \mathrm{P}_{\mathrm{t}}\right.$, $\mathrm{P}_{\mathrm{o}}, \mathrm{sP}_{\mathrm{o}}, \mathrm{P}_{\mathrm{b}} / \mathrm{P}_{\mathrm{o}}$, and $\mathrm{P}_{\mathrm{t}} / \mathrm{P}_{\mathrm{o}}$ ) are summarized in Table 2 . The results of the Tukey-Kramer method for all 120 pairwise comparisons of variables between groups are summarized in Fig. 1 for the five original experimental groups.

None of the 12 variables differed between adult mouse EDL and adult mouse SOL myooids (Fig. 1). Consequently, these data were pooled, and the Tukey-
Kramer method was again applied to the data set (Fig. 2 ). When the pairwise comparisons between the resulting four experimental groups were examined, several trends were apparent. No differences were observed for $\mathrm{C}_{50}$ or $\mathrm{dP} / \mathrm{d} t$. Differences for CSA, $\mathrm{P}_{\mathrm{t}}$, and $\mathrm{P}_{\mathrm{o}}$ were each detected in only one of the six comparisons. $\mathrm{R}_{50}$, TPT, $\mathrm{RT}_{1 / 2}$, and $\mathrm{sP}_{\mathrm{o}}$ were different in three of the six comparisons, $\mathrm{P}_{b}$ in four comparisons, and $\mathrm{P}_{b} / \mathrm{P}_{\mathrm{o}}$ and $\mathrm{P}_{t} / \mathrm{P}_{\mathrm{o}}$ in five comparisons (Fig. 2).

The hypothesis that the excitability and contractility of primary rodent myooids are not different was not supported, since 1) the adult mouse myooids had a mean $\mathrm{sP}_{\mathrm{o}}$ of $15.6 \mathrm{kN} / \mathrm{m}^{2}$, greater than the $4.2 \mathrm{kN} / \mathrm{m}^{2}$ for the adult rat myooids, and 2) for neonatal rat myooids, six variables differed compared with the pooled adult mouse myooids and three differed compared with adult rat myooids (Fig. 2). Neonatal rat myooids had greater $\mathrm{P}_{\mathrm{b}}$ and $\mathrm{P}_{\mathrm{b}} / \mathrm{P}_{\mathrm{o}}$ and lower $\mathrm{P}_{\mathrm{t}} / \mathrm{P}_{\mathrm{o}}$ than either adult rodent myooid group.

Our hypothesis that the excitability and contractility of $\mathrm{C}_{2} \mathrm{C}_{12}-10 \mathrm{~T}^{1 / 2} / 2$ myooids differed from those of primary rodent myooids was supported, since $\mathrm{C}_{2} \mathrm{C}_{12^{-}}-10 \mathrm{~T} 1 / 2$ myooids differed from adult mouse myooids in 8 of the 12 variables, from adult rat myooids in 6 of the 12 variables, and from neonatal rat myooids in 5 of the 12 variables (Fig. 2). In all cases, the $\mathrm{C}_{2} \mathrm{C}_{12}-10 \mathrm{~T}^{1 / 2} \mathrm{2}$ myooids were different from primary rodent myooids in terms of $\mathrm{R}_{50}$, TPT, $\mathrm{RT}_{1 / 2}, \mathrm{P}_{\mathrm{b}} / \mathrm{P}_{\mathrm{o}}$, and $\mathrm{P}_{\mathrm{t}} / \mathrm{P}_{\mathrm{o}}$. The $\mathrm{C}_{2} \mathrm{C}_{12}-$ $10 \mathrm{~T}^{1} / 2$ myooids had a greater CSA than the pooled mouse myooids (Fig. 2). In all comparisons, the $\mathrm{C}_{2} \mathrm{C}_{12^{-}}$ $10 \mathrm{~T}^{1} 1 / 2$ myooids had higher $R_{50}$. The higher $R_{50}$ indicated that the myotubes formed from $\mathrm{C}_{2} \mathrm{C}_{12}$ cells required larger stimulus amplitude and, thus, had lower excitability than myotubes formed from any of the

Table 2. Baseline passive force and contractility of myooids

\begin{tabular}{|c|c|c|c|c|c|c|c|}
\hline $\begin{array}{c}\text { Experimental } \\
\text { Group }\end{array}$ & $n$ & $\mathrm{P}_{\mathrm{b}}, \mu \mathrm{N}$ & $\mathrm{P}_{\mathrm{t}}, \mu \mathrm{N}$ & $\mathrm{P}_{\mathrm{o}}, \mu \mathrm{N}$ & $\mathrm{sP}_{\mathrm{o}}, \mathrm{kN} / \mathrm{m}^{2}$ & $\mathrm{P}_{\mathrm{b}} / \mathrm{P}_{\mathrm{o}}$ & $\mathrm{P}_{\mathrm{t}} / \mathrm{P}_{\mathrm{o}}$ \\
\hline $\mathrm{C}_{2} \mathrm{C}_{12}-10 \mathrm{~T}^{1 / 2}$ & 19 & $371 \pm 52$ & $156 \pm 27$ & $214 \pm 37$ & $4.5 \pm 1.6$ & $2.12 \pm 0.23$ & $0.74 \pm 0.02$ \\
\hline Neonatal rat & 11 & $306 \pm 32$ & $48 \pm 9$ & $115 \pm 18$ & $4.0 \pm 1.5$ & $3.16 \pm 0.52$ & $0.43 \pm 0.05$ \\
\hline Adult rat SOL & 11 & $124 \pm 30$ & $139 \pm 24$ & $224 \pm 33$ & $4.2 \pm 1.2$ & $0.55 \pm 0.08$ & $0.59 \pm 0.02$ \\
\hline Mouse SOL & 7 & $38 \pm 14$ & $321 \pm 109$ & $576 \pm 199$ & $19.2 \pm 5.1$ & $0.10 \pm 0.03$ & $0.60 \pm 0.04$ \\
\hline Mouse EDL & 4 & $37 \pm 28$ & $162 \pm 125$ & $281 \pm 218$ & $9.2 \pm 4.7$ & $0.17 \pm 0.06$ & $0.55 \pm 0.0$ \\
\hline Mouse pooled & 11 & $38 \pm 13$ & $263 \pm 83$ & $469 \pm 149$ & $15.6 \pm 3.8$ & $0.12 \pm 0.03$ & $0.58 \pm 0.0$ \\
\hline
\end{tabular}

Values are means $\pm \mathrm{SE} . \mathrm{P}_{\mathrm{b}}$, passive baseline force; $\mathrm{P}_{\mathrm{o}}$, peak isometric force; $\mathrm{sP}_{\mathrm{o}}$, specific force; calculated by dividing $\mathrm{P}_{\mathrm{o}}$ by CSA, based on the myooid diameter. 


\begin{tabular}{|c|c|c|c|c|c|c|c|c|c|c|c|c|c|c|c|c|}
\hline & \multicolumn{4}{|c|}{ Neonatal } & \multicolumn{4}{|c|}{ Rat SOL } & \multicolumn{4}{|c|}{ Mouse SOL } & \multicolumn{4}{|c|}{ Mouse EDL } \\
\hline $\begin{array}{l}\mathrm{C} 2 \mathrm{C} 12- \\
10 \mathrm{~T} 1 / 2\end{array}$ & & $\begin{array}{c}R_{50} \\
R_{1 / 2}\end{array}$ & & $\begin{array}{l}\text { TPT } \\
P_{t} / P_{0}\end{array}$ & & $\begin{array}{c}R_{50} \\
R_{1 / 2}\end{array}$ & $\begin{array}{c}\mathbf{P}_{\mathrm{b}} \\
\mathbf{P}_{\mathrm{b}} / \mathbf{P}_{\mathrm{o}}\end{array}$ & $\begin{array}{c}\text { TPT } \\
P_{t} / P_{0}\end{array}$ & $P_{0}$ & $\begin{array}{c}R_{50} \\
R T_{1 / 2} \\
\mathbf{s P}_{0}\end{array}$ & $\begin{array}{c}P_{b} \\
P_{b} / P_{0}\end{array}$ & $\begin{array}{c}\text { TPT } \\
P_{t} / P_{0}\end{array}$ & & $\begin{array}{c}R_{50} \\
R T_{1 / 2}\end{array}$ & $\begin{array}{c}\mathbf{P}_{b} \\
\mathbf{P}_{\mathbf{b}} / \mathbf{P}_{0}\end{array}$ & $\begin{array}{c}\text { TPT } \\
P_{t} / P_{0}\end{array}$ \\
\hline $\begin{array}{l}\text { Mouse } \\
\text { EDL }\end{array}$ & & $\mathbf{R}_{\mathbf{5 0}}$ & $\begin{array}{c}P_{b} \\
P_{b} / P_{0}\end{array}$ & & & $\mathbf{R}_{50}$ & & & & & & & & & & \\
\hline $\begin{array}{l}\text { Mouse } \\
\text { SOL }\end{array}$ & $\mathbf{P}_{\mathbf{o}}$ & $\mathbf{s} \mathbf{P}_{0}$ & $\begin{array}{c}\mathbf{P}_{b} \\
\mathbf{P}_{b} / \mathbf{P}_{0}\end{array}$ & $\begin{array}{c}P_{t} \\
P_{t} / P_{0}\end{array}$ & $\mathbf{P}_{\mathbf{o}}$ & $\mathbf{s} \mathbf{P}_{\mathbf{0}}$ & & & & & & & & LEG & ND: & \\
\hline $\begin{array}{l}\text { Rat } \\
\text { SOL }\end{array}$ & & & $\mathbf{P}_{\mathbf{b}} / \mathbf{P}_{\mathbf{0}}$ & $P_{t} / P_{0}$ & & & & & & & & & $\begin{array}{c}\mathrm{CSA} \\
\mathrm{dP} / \mathrm{dt} \\
\mathrm{P}_{\mathrm{o}}\end{array}$ & $\begin{array}{c}\mathbf{R}_{50} \\
\mathbf{R T}_{1 / 2} \\
\mathbf{S P}_{0}\end{array}$ & $\begin{array}{c}\mathbf{C}_{50} \\
\mathbf{P}_{\mathbf{b}} \\
\mathbf{P}_{\mathbf{b}} / \mathbf{P}_{\mathrm{o}}\end{array}$ & $\begin{array}{c}\text { TPT } \\
P_{t} \\
P_{t} / P_{0}\end{array}$ \\
\hline
\end{tabular}

Fig. 1. Summary of paired comparisons, using the Tukey-Kramer method, of myooid excitability and isometric contractile function data. Data were analyzed using the Tukey-Kramer method for all pairwise comparisons between treatment means, with significance threshold set at $\alpha \leq 0.05$. This analysis compared the means of 12 parameters [cross-sectional area (CSA), rheobase $\left(\mathrm{R}_{50}\right)$, chronaxie $\left(\mathrm{C}_{50}\right)$, time to peak tension (TPT), rate of force development $(\mathrm{dP} / \mathrm{d} t)$, one-half relaxation time $\left(\mathrm{RT}_{1 / 2}\right)$, passive baseline force $\left(\mathrm{P}_{\mathrm{b}}\right)$, peak twitch force $\left(\mathrm{P}_{\mathrm{t}}\right)$, peak isometric force $\left(\mathrm{P}_{\mathrm{o}}\right), \mathrm{P}_{\mathrm{b}} / \mathrm{P}_{\mathrm{o}}, \mathrm{P}_{\mathrm{t}} / \mathrm{P}_{\mathrm{o}}$, and specific force $\left.\left(\mathrm{sP}_{\mathrm{o}}\right)\right]$ for 5 different experimental groups or "treatments" $\left[\mathrm{C}_{2} \mathrm{C}_{12}-10 \mathrm{~T}^{1 / 2}\right.$, neonatal rat, rat soleus (SOL), mouse SOL, and mouse extensor digitorum longus (EDL)]. Comparisons with significant differences between means are entered. Each of the 10 boxes, for comparisons between treatments, contains all 12 experimental parameters, displayed in the legend. Each parameter always occupies the same position within each box; e.g., TPT is always at top right. Within each box, a parameter is displayed only if the difference between the means is significant. With the use of this method to display the results of the Tukey-Kramer analysis of the data, it is possible to readily detect trends in the significant differences between treatments. For example, in no case was the CSA significantly different between treatments, whereas the $\mathrm{C}_{2} \mathrm{C}_{12}-10 \mathrm{~T} 1 / 2$ treatment differed significantly from all other treatments when $\mathrm{R}_{50}, \mathrm{TPT}, \mathrm{RT}_{1 / 2}$, and $\mathrm{P}_{\mathrm{t}} / \mathrm{P}_{\mathrm{o}}$ were considered.

primary cell sources. For $\mathrm{C}_{2} \mathrm{C}_{12}-10 \mathrm{~T}^{1 / 2}$ myooids, the $\mathrm{RT}_{1 / 2}$ was an order of magnitude longer than the $\mathrm{RT}_{1 / 2}$ for any of the other myooids.

Life span of myooids in culture. Myooids spontaneously contracted throughout their life span. Typically, the diameter decreased steadily until the myooid broke, usually during a media change after the diameter had decreased to $<50 \mu \mathrm{m}$. The average and maximum life spans for adult mouse SOL and neonatal and adult rat SOL myooids are presented in Fig. 3. Adult mouse SOL myooids, plated at $10 \mathrm{mg}$ of dissociated tissue per plate, remained viable in culture for an average of $101 \pm 12(\mathrm{SE})$ days $(n=8)$, with a maximum observed life span of 168 days. Neonatal rat myooids plated at $1 \times 10^{6}$ cells $/ \mathrm{cm}^{2}$ were viable for an average of $52 \pm 2.5$ days $(n=25)$, with a maximum observed life span of 69 days. Adult rat SOL myooids, plated at $13 \mathrm{mg}$ of dissociated tissue per plate, remained viable for an average of $74 \pm 6$ days $(n=11)$, with a maximum observed life span of 127 days.

The myooids were suspended above the substrate under continuous tension between the artificial ten- dons. This observation is consistent with the previous report that myooids were under significant passive tension at the length $\left(L_{\mathrm{c}}\right)$ at which they were cultured (5). The myooids in the life span groups were left undisturbed until the myooids broke, so their $\mathrm{P}_{\mathrm{b}}$ was not measured. The $\mathrm{P}_{b}$ data from the contractile function groups were used to estimate the initial $\mathrm{P}_{\mathrm{b}}$, at $\sim 32$ days in culture, of the myooids in the corresponding life span groups (adult mouse SOL and neonatal and adult rat SOL). The life span for each group was then plotted against the estimated $\mathrm{P}_{\mathrm{b}}$. Myooids with higher $\mathrm{P}_{\mathrm{b}}$ had correspondingly shorter life spans in culture (Fig. 4).

\section{DISCUSSION}

The $\mathrm{sP}_{\mathrm{o}}$ for whole muscles from adult rats is $\sim 250$ $\mathrm{kN} / \mathrm{m}^{2}(3)$. Few reports exist of the $\mathrm{sP}_{\mathrm{o}}$ of mammalian skeletal muscle at early stages of development, but the $\mathrm{sP}_{\mathrm{o}}$ for SOL and EDL muscles of newborn Wistar rats were 44 and $74 \mathrm{kN} / \mathrm{m}^{2}$, respectively (2). The low values of $\mathrm{sP}_{\mathrm{o}}$ of skeletal muscles from newborn rats, only 18 and $30 \%$ of values for adult rats, have been attributed
Fig. 2. Paired comparisons of myooid function, with mouse data pooled. For the original 5 experimental groups, no differences were detected between means for any of the 12 experimental parameters when mouse SOL and mouse EDL groups were compared. Mouse SOL and EDL data were pooled, reducing the total to 4 experimental groups or treatments. Data were reanalyzed using the Tukey-Kramer method. As in Fig. 1, each parameter in each box is displayed only if the difference between means is significant at $\alpha \leq$ 0.05 .

\begin{tabular}{|c|c|c|c|c|c|c|c|c|c|c|c|}
\hline & \multicolumn{4}{|c|}{ Neonatal } & \multicolumn{3}{|c|}{ Rat SOL } & \multicolumn{4}{|c|}{ Pooled Mouse } \\
\hline $\begin{array}{l}\mathrm{C} 2 \mathrm{C} 12- \\
10 \mathrm{~T} 1 / 2\end{array}$ & & $\begin{array}{c}R_{50} \\
R T_{1 / 2}\end{array}$ & $\mathbf{P}_{\mathrm{b}} / \mathbf{P}_{\mathrm{o}}$ & $\begin{array}{l}\text { TPT } \\
P_{\mathrm{t}} / \mathrm{P}_{\mathrm{o}}\end{array}$ & $\begin{array}{c}\mathbf{R}_{50} \\
\mathrm{RT}_{1 / 2}\end{array}$ & $\begin{array}{c}\mathbf{P}_{\mathbf{b}} \\
\mathbf{P}_{\mathrm{b}} / \mathbf{P}_{\mathrm{o}}\end{array}$ & $\begin{array}{l}\text { TPT } \\
P_{t} / P_{0}\end{array}$ & CSA & $\begin{array}{c}R_{50} \\
R^{2} T_{1 / 2} \\
\mathbf{s P}_{0}\end{array}$ & $\begin{array}{c}\mathbf{P}_{\mathbf{b}} \\
\mathbf{P}_{\mathrm{b}} / \mathbf{P}_{\mathrm{o}}\end{array}$ & $\begin{array}{l}\text { TPT } \\
P_{\mathfrak{t}} / P_{0}\end{array}$ \\
\hline $\begin{array}{l}\text { Pooled } \\
\text { Mouse }\end{array}$ & $\mathbf{P}_{\mathbf{0}}$ & $\mathbf{s P}_{0}$ & $\begin{array}{c}\mathbf{P}_{\mathbf{b}} \\
\mathbf{P}_{b} / \mathbf{P}_{\mathbf{a}}\end{array}$ & $\begin{array}{c}\mathbf{P}_{\mathbf{t}} \\
\mathbf{P}_{\mathbf{t}} / \mathbf{P}_{0}\end{array}$ & $\mathbf{s} \mathbf{P}_{0}$ & & & & LEG & ND: & \\
\hline $\begin{array}{l}\text { Rat } \\
\text { SOL }\end{array}$ & & & $\begin{array}{c}\mathbf{P}_{\mathbf{b}} \\
\mathbf{P}_{b} / \mathbf{P}_{0}\end{array}$ & $P_{t} / P_{0}$ & & & & $\begin{array}{c}\text { CSA } \\
d P / d t \\
P_{0}\end{array}$ & $\begin{array}{c}\mathbf{R}_{50} \\
\mathrm{RT}_{1 / 2} \\
\mathbf{s P}_{0}\end{array}$ & $\begin{array}{c}\mathbf{C}_{50} \\
P_{b} \\
P_{b} / P_{0}\end{array}$ & $\begin{array}{c}\text { TPT } \\
P_{t} \\
P_{t} P_{0}\end{array}$ \\
\hline
\end{tabular}




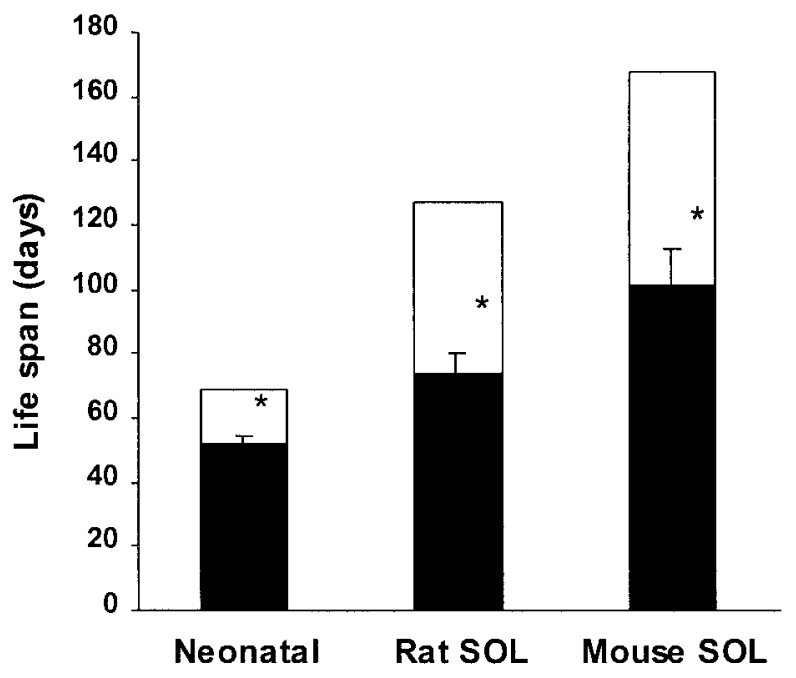

Fig. 3. Life span of myooids in culture. Solid bars, mean life span for each group; error bars, SE. Open bars, maximum observed life span for a myooid within each group. Myooids from neonatal rat muscle, plated at $1 \times 10^{6}$ cells $/ \mathrm{cm}^{2}$ on $1.0 \mu \mathrm{g} / \mathrm{cm}^{2}$ laminin with suture anchors, were viable for an average of $52 \pm 2.5$ days $(n=25)$, with a maximum observed life span of 69 days. Myooids from adult rat soleus, plated at $13 \mathrm{mg}$ of dissociated tissue per plate on $1.0 \mu \mathrm{g} / \mathrm{cm}^{2}$ laminin with suture anchors, continued to remain viable for an average of $74 \pm 6$ days $(n=11)$, with a maximum observed life span of 127 days. Myooids from mouse SOL muscle, plated at $10 \mathrm{mg}$ of dissociated tissue per plate on $1.0 \mu \mathrm{g} / \mathrm{cm}^{2}$ laminin with suture anchors, remained viable in culture for an average of $101 \pm 12$ days $(n=8)$, with a maximum observed life span of 168 days. A one-way ANOVA followed by Bonferroni comparisons when significance was detected $(P \leq 0.05)$ indicated that each of the life spans for each of the types of myooids was significantly different from the other two.

to the presence of embryonic and neonatal isoforms of myosin heavy chain (MHC) present in neonatal (11) and developing muscles (18). For each of the five groups of myooids, $\mathrm{sP}_{\mathrm{o}}$ of $4-19 \mathrm{kN} / \mathrm{m}^{2}$ are $5-43 \%$ of the values for muscles of newborn rats and $2-8 \%$ of the values for muscles of adult rats. Of the myooids, the $\mathrm{C}_{2} \mathrm{C}_{12}-10 \mathrm{~T}^{1 / 2} / 2$, neonatal rat and adult rat myooids had the lowest values for $\mathrm{sP}_{\mathrm{o}}, \sim 4 \mathrm{kN} / \mathrm{m}^{2}$, whereas the adult mouse myooids had the highest values, $16 \mathrm{kN} / \mathrm{m}^{2}$. On the basis of the $\mathrm{sP}_{\mathrm{o}}$, myooids in each of five groups appear to have poorly developed contractile apparatus, in addition to the possibility of the expression of predominantly developmental isoforms of MHC (18).

Although direct measurements of the MHC isoform composition of myooids have not been made, the timedependent characteristics of the twitch, TPT, $\mathrm{RT}_{1 / 2}$, and $\mathrm{dP} / \mathrm{d} t$, as well as $\mathrm{P}_{\mathrm{t}} / \mathrm{P}_{\mathrm{o}}$, are consistent with the hypothesis that the predominant myosin isoforms in myooids are developmental, not adult, isoforms. For myooids from each of the primary cultures of muscles from mice or rats, TPT was 50-65 ms, values within the range reported for SOL and EDL muscles of newborn rats $(2,6)$. Even for the newborn rats, $\mathrm{RT}_{1 / 2}$ varies more widely than the TPT, with a value of $70 \mathrm{~ms}$ for the SOL muscles and $50 \mathrm{~ms}$ for the EDL muscles. Only the pooled mouse myooid experimental group had an $\mathrm{RT}_{1 / 2}$ in this range, $62 \mathrm{~ms}$, and in the remainder of the myooids from primary cultures $\mathrm{RT}_{1 / 2}$ ranged from 81 to
$100 \mathrm{~ms}$. The TPT and $\mathrm{RT}_{1 / 2}$ of the $\mathrm{C}_{2} \mathrm{C}_{12}-10 \mathrm{~T}^{1 / 2}$ myooids were considerably more prolonged than the values for other myooids. The time-dependent characteristics of the myooid twitches appear to be dependent on the same mechanisms that impose the differences in the force-velocity relationships of neonatal and adult muscles, namely, the rate of $\mathrm{Ca}^{2+}$ release and reuptake in muscle as a function of age from birth $(2,6)$. The similarity of the TPT and $\mathrm{RT}_{1 / 2}$ of the mouse and rat myooids, regardless of age of the donor, to those of the newborn rats is in contrast to the widely divergent values for the $\mathrm{C}_{2} \mathrm{C}_{12}-10 \mathrm{~T}_{1 / 2}$ myooids. The magnitude of the differences for the $\mathrm{C}_{2} \mathrm{C}_{12}-10 \mathrm{~T}^{1 / 2}$ myooids suggests major impairments in development of this cell line in culture.

The maximum rate of rise of force has been used to study the developmental changes in skeletal muscles of neonatal and young rats $(2,6)$. When normalized as a percentage of the rise in $P_{0}$, the maximum rate of rise of force correlates strongly with the maximum velocity of shortening (2). The maximum rate of rise of force in skeletal muscles is low at birth, largely because of the low actomyosin ATPase activity (6), but increases rapidly to achieve adult values after the first month. During this period, the maximum rate of rise of force increases fivefold (6) and the maximum velocity of unloaded shortening of the EDL muscles doubles (2). The $\mathrm{dP} / \mathrm{d} t$ values of the myooids, expressed in absolute terms of micronewtons per millisecond, were at least four to five orders of magnitude slower than values of 45 and $120 \mathrm{mN} / \mathrm{ms}$ reported for SOL and EDL muscles of adult rats $(6,20)$ and were still two orders of magnitude slower when expressed as a percentage of the $\mathrm{P}_{\mathrm{o}}$. These data suggest that the capacity of the myooids to develop force rapidly and to shorten at high velocity

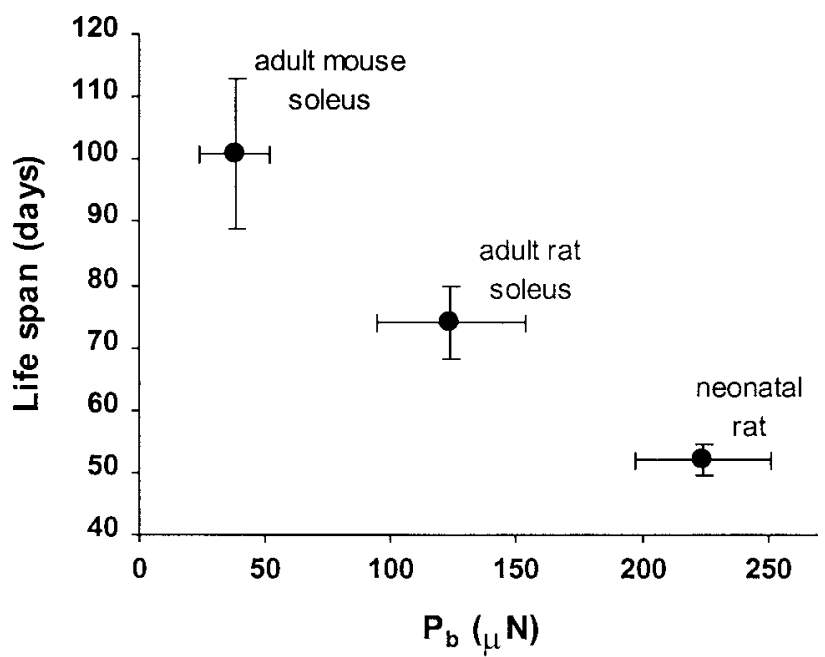

Fig. 4. Effect of $P_{b}$ on life span of myooids in culture. Life span data are from the 3 life span experimental groups; $P_{b}$ data are from the 3 corresponding contractile function experimental groups. $\mathrm{P}_{\mathrm{b}}$ data could not be collected from the life span groups because the measurement of contractile properties was not carried out in an aseptic environment, so myooids were not replaced in culture after measurement of contractile properties. Thus $\mathrm{P}_{\mathrm{b}}$ data represent means at $\sim 32$ days in culture. Error bars, SE. 
is even more impaired than their ability to generate $\mathrm{sP}_{\mathrm{o}}$.

The $\mathrm{P}_{\mathrm{t}} / \mathrm{P}_{\mathrm{o}}$ of the four groups of primary rodent myooids ranged from 0.43 to 0.60 . These values for $\mathrm{P}_{t} / \mathrm{P}_{\mathrm{o}}$ compare favorably with $0.60 \pm 0.05$ (SD) and $0.53 \pm$ 0.08 reported for SOL and EDL muscles of newborn rats, respectively (2). The ratio decreases rapidly and stabilizes within the 1st mo of life at the adult values of 0.25 for SOL muscles and 0.19 for EDL muscles. As with the other variables, the $\mathrm{P}_{\mathrm{t}} / \mathrm{P}_{\mathrm{o}}$ of the $\mathrm{C}_{2} \mathrm{C}_{12}-10 \mathrm{~T}^{1} / 2$ myooids was outside the range of the other groups. The similarity of the $\mathrm{P}_{\mathrm{t}} / \mathrm{P}_{\mathrm{o}}$ data for rodent myooids to that of neonatal and newborn rodents, as well as the timedependent properties of the twitch, support the conclusion that the myooids are arrested in the state wherein they express predominantly, if not exclusively, embryonic and neonatal isoforms of myosin $(2,11,18)$.

The absence of any differences in the excitability or contractility for adult mouse myooids, whether engineered from SOL or EDL muscles, indicates that myooids can be developed from muscles expressing exclusively either slow and intermediate or fast isoforms of $\mathrm{MHC}$ (16). Unexpectedly, a fourfold greater $\mathrm{sP}_{\mathrm{o}}$ was observed for pooled adult mouse myooids than for adult rat SOL myooids. We have no explanation for such a large difference in such a critical measure of function, particularly in the absence of any other difference between these two groups.

The lower excitability and contractility of $\mathrm{C}_{2} \mathrm{C}_{12}$ $10 \mathrm{~T}^{1} / 2$ myooids than of the primary cultures of rodent myooids may be attributable to the lack of normal metabolism, phenotype, or growth regulation of $\mathrm{C}_{2} \mathrm{C}_{12}$ myoblasts $(8,13,24)$. Even when cultured with $10 \mathrm{~T}^{1 / 2}$ fibroblasts, $\mathrm{C}_{2} \mathrm{C}_{12}$ myoblasts formed myooids only onehalf as reliably as the $95 \%$ success rate for the formation of myooids from primary cultures of skeletal muscles from neonatal and adult rodents. The differences between the $\mathrm{C}_{2} \mathrm{C}_{12}-10 \mathrm{~T} 1 / 2$ myooids and the primary culture myooids were spread over more than one-half of the 12 variables. Interestingly, one variable that did not differ among the groups was $\mathrm{C}_{50}$, which ranged from 416 to $603 \mu \mathrm{s}$. In contrast, $\mathrm{R}_{50}$ for the $\mathrm{C}_{2} \mathrm{C}_{12}-10 \mathrm{~T} 1 / 2$ myooids was two- to fourfold greater than that of any other group. Despite the lack of an explanation for the reduced excitability of the $\mathrm{C}_{2} \mathrm{C}_{12}-10 \mathrm{~T}^{1 / 2}$ myooids, the functional data taken as a whole suggest important differences in the cellular organization and chemomechanical coupling of $\mathrm{C}_{2} \mathrm{C}_{12}$-derived myotubes compared with primary myotubes.

Fibroblasts assist in extracellular matrix formation during myogenesis in vitro $(7,12,19,21,22,28) . \mathrm{C}_{2} \mathrm{C}_{12}$ myoblasts did not form myooids when monocultured, yet they formed myooids with some success when cocultured with fibroblasts, substantiating the critical role of fibroblasts in the formation of myooids. As reported earlier (5), fibroblasts generally oriented around the periphery and along the total length of the myooid. Apparently, in primary cultures of skeletal muscles of mice and rats, the simple dissociation of muscle tissue used for this study provided an adequate source of myoblasts and fibroblasts for the formation of the myooids. The $\mathrm{P}_{\mathrm{b}}$ of myooids may be generated by the fibroblasts within the myooid, because fibroblasts generate tensile forces in culture in the presence of serum $(9,10)$. Since larger baseline forces also correlate with shorter myooid life span in culture, further studies should consider the influence of fibroblasts in myooid function and longevity.

The primary limitation with the myooid model as presented is the failure of the myotubes in the myooid to express a fully adult phenotype, in terms of sarcomere structure, excitability, and contractility. We hypothesize that the arrested developmental state of the myotubes involves the expression of chiefly embryonic and neonatal isoforms of myosin, resulting from the culture conditions we imposed, in which there was no application of mechanical strain, either active or passive, no electrical stimulation, and no innervation. As such, the data presented form the basis for future experiments in which experimental interventions can be applied to study the effect of controlled mechanical strain, electrical stimulation, nerve-muscle coculture, and addition of growth factors and trophic agents on muscle development, contractility, and excitability in culture. Thus myooids could prove to be useful in the study of skeletal muscle organogenesis, synaptogenesis, and chemomechanical transduction. The presence of the suture anchors allows the attachment of force transducers and servo motors, so that controlled mechanical strain may be applied while forces are monitored. The three-dimensional, cylindrical structure permits electrical fields to be generated across the tissue more easily and accurately than is possible with a cell monolayer, facilitating chronic exposure of the tissue to electrical fields to influence development as well as activation of the tissue for functional evaluation.

Myooids may also be used for studying the physiology of muscle engineered from cells from animals with neonatal-lethal mutations affecting skeletal muscle, stem cell incorporation into muscle tissue, and plasticity and function of skeletal muscle engineered from the satellite cells of aged mammals. If the myooid model is adapted for use with human tissue, it could be used to test the effectiveness of specific gene therapy approaches to correct such disorders as malignant hyperthermia or muscular dystrophy. Tissue samples or tissue from human fetal tissue banks could be employed, thus eliminating the risks inherent to the introduction of genetic material into living humans until the effectiveness of the therapy in human muscle tissue can be established.

In summary, functional three-dimensional skeletal muscle constructs may be engineered from primary cultures of cells from fast and slow muscles of neonatal and adult rodents. The muscle constructs develop without the use of synthetic scaffolds to support the contractile section of the muscle and can be maintained in culture for several months. The excitability and contractility of myooids is similar to that which would be expected from embryonic or neonatal muscle tissue under conditions of chronic denervation. On the basis 
of the consistency, diversity, and magnitude of the differences between the $\mathrm{C}_{2} \mathrm{C}_{12}-10 \mathrm{~T}^{1} / 2$ myooids and primary adult rodent myooids, the $\mathrm{C}_{2} \mathrm{C}_{12}$ cells appear to be less suitable than adult rodent primary cultures for engineering functional muscle constructs.

The authors thank Cheryl Hassett for assistance in the development of the surgical techniques used for the neonatal rat dissections and histology, Dr. Krystyna Pasyk for assistance with histological sections for this research, Dr. Giovanni Salvatori for providing the $10 \mathrm{~T}^{1} 12$ fibroblasts, and Dr. Joseph Chromiak (Brown University) for invaluable assistance and advice on the details of neonatal skeletal muscle primary culture.

This work was supported by a pilot grant from the University of Michigan Center for Biomedical Engineering Research, by National Institute on Aging Grant RO1-AG-06157, and by access to space and resources in the Contractility Core of the Nathan Shock Center in the Institute of Gerontology at the University of Michigan.

\section{REFERENCES}

1. Chromiak JA, Shansky J, Perrone C, and Vandenburgh HH. Bioreactor perfusion system for the long-term maintenance of tissue-engineered skeletal muscle organoids. In Vitro Cell Dev Biol Anim 34: 694-703, 1998.

2. Close R. Dynamic properties of fast and slow skeletal muscles of the rat during development. J Physiol (Lond) 173: 74-95, 1964.

3. Close RI. Dynamic properties of mammalian skeletal muscles. Physiol Rev 52: 129-197, 1972.

4. Cognard C, Constantin B, Rivet-Bastide M, Imbert N, Besse C, and Raymond G. Appearance and evolution of calcium currents and contraction during the early post-fusional stages of rat skeletal muscle cells developing in primary culture. Development 117: 1153-1161, 1993.

5. Dennis RG and Kosnik PE. Excitability and isometric contractile properties of mammalian skeletal muscle constructs engineered in vitro. In Vitro Cell Dev Biol Anim 36: 327-335, 2000.

6. Drachman DB and Johnston DM. Development of a mammalian fast muscle: dynamic and biochemical properties correlated. J Physiol (Lond) 234: 29-42, 1973

7. Hantai D, Tassin AM, Gautron J, and Labat-Robert J. Biosynthesis of laminin and fibronectin by rat satellite cells during myogenesis in vitro. Cell 9: 647-654, 1985.

8. Irintchev A, Rosenblatt JD, Cullen MJ, Zweyer M, and Wernig A. Ectopic skeletal muscles derived from myoblasts implanted under the skin. J Cell Sci 111: 3287-3297, 1998.

9. James DW and Taylor JF. The stress developed by sheets of chick fibroblasts in vitro. Exp Cell Res 54: 107-110, 1969.

10. Kolodney MS and Wysolmerski RB. Isometric contraction by fibroblasts and endothelial cells in tissue culture: a quantitative study. J Cell Biol 117: 73-82, 1992.

11. LaFramboise WA, Daood MJ, Guthrie RD, Butler-Browne GS, Whalen RG, and Ontell M. Myosin isoforms in neonatal rat extensor digitorum longus, diaphragm, and soleus muscles. Am J Physiol Lung Cell Mol Physiol 259: L116-L122, 1990.

12. Mayne R, Swasdison S, Sanderson RD, and Irwin MH. Extracellular Matrix, Fibroblasts and the Development of Skeletal Muscle. Cellular and Molecular Biology of Muscle Development. New York: Liss, 1989, p. 107-116.

13. Miller RR, Rao JS, Burton WV, and Festoff BW. Proteoglycan synthesis by clonal skeletal muscle cells during in vitro myogenesis: differences detected in the types and patterns from primary cultures. Int J Dev Neurosci 9: 259-267, 1991.

14. Neter J, Wasserman W, and Kutner MH. Applied Linear Statistical Models. Chicago, IL: Irwin, 1996.

15. Okano T and Matsuda T. Tissue engineered skeletal muscle: preparation of highly dense, highly oriented hybrid muscular tissues. Cell Transplant 7: 71-82, 1998.

16. Phillips SK, Wiseman RW, Woledge RC, and Kushmerick MJ. Neither changes in phosphorus metabolite levels nor myosin isoforms can explain the weakness in aged mouse muscle. J Physiol (Lond) 463: 157-167, 1993.

17. Powell C, Shansky J, Del Tatto M, Forman DE, Hennessey J, Sullivan K, Zielinski BA, and Vandenburgh HH. Tissueengineered human bioartificial muscles expressing a foreign recombinant protein for gene therapy. Hum Gene Ther 10: 565577, 1999.

18. Reiser PJ, Kasper CE, Greaser ML, and Moss RL. Functional significance of myosin transitions in single fibers of developing soleus muscle. Am J Physiol Cell Physiol 254: C605-C613, 1988.

19. Sanderson RD, Fitch JM, Linsenmayer TR, and Mayne R. Fibroblasts promote the formation of a continuous basal lamina during myogenesis in vitro. J Cell Biol 102: 740-747, 1986

20. Segal SS and Faulkner JA. Temperature-dependent physiological stability of rat skeletal muscle in vitro. Am J Physiol Cell Physiol 248: C265-C270, 1985.

21. Shansky J, Del Tatto M, Chromiak J, and Vandenburgh $\mathbf{H}$. A simplified method for tissue engineering skeletal muscle organoids in vitro. In Vitro Cell Dev Biol Anim 33: 659-661, 1997.

22. Strohman RC, Bayne E, Spector D, Obinata T, MicouEastwood J, and Maniotis A. Myogenesis and histogenesis of skeletal muscle on flexible membranes in vitro. In Vitro Cell Dev Biol 26: 201-208, 1990

23. Swasdison S and Mayne R. Formation of highly organized skeletal muscle fibers in vitro. Comparison with muscle development in vivo. J Cell Sci 102: 643-652, 1992.

24. Turner DC. Cell-cell and cell-matrix interactions in the morphogenesis of skeletal muscle. Dev Biol 3: 205-224, 1986.

25. Vandenburgh H, Chromiak J, Shansky J, Del Tatto M, and LeMaire J. Space travel directly induces skeletal muscle atrophy. FASEB J 13: 1031-1038, 1999.

26. Vandenburgh H, Del Tatto M, Shansky J, Goldstein L, Russell K, Genes N, Chromiak J, and Yamada S. Attenuation of skeletal muscle wasting with recombinant human growth hormone secreted from a tissue-engineered bioartificial muscle. Hum Gene Ther 9: 2555-2564, 1998.

27. Vandenburgh H, Del Tatto M, Shansky J, LeMaire J, Chang A, Payumo F, Lee P, Goodyear A, and Raven L. Tissue-engineered skeletal muscle organoids for reversible gene therapy. Hum Gene Ther 7: 2195-2200, 1996.

28. Vandenburgh HH, Swasdison S, and Karlisch P. Computeraided mechanogenesis of skeletal muscle organs from single cells in vitro. FASEB J 5: 2860-2867, 1991.

29. Van Wachem PB, Brouwer LA, and van Luyn MJ. Absence of muscle regeneration after implantation of a collagen matrix seeded with myoblasts. Biomaterials 20: 419-426, 1999.

30. Van Wachem PB, van Luyn MJ, and da Costa ML. Myoblast seeding in a collagen matrix evaluated in vitro. J Biomed Mater Res 30: 353-360, 1996. 